\title{
Nucleotide Polymorphism of Leptin Gene in Anatolian Water Buffaloes
}

\author{
Selçuk Kaplan \\ Namik Kemal University, Faculty of Veterinary Medicine, Department of Genetics, \\ Tekirdag, 59100, Turkey
}

\begin{abstract}
A B S T R A C T
Marker assisted selection (MAS) have been using to determine the associations between the genes and economic traits of livestock animals. However, phenotypic values do not generally indicate the real genotypic values of animals. However, using MAS approaches in selection of animals can increase the accuracy of selection. From this point of view, validation of candidate gene markers for marker assisted selection is very important to increase genetic gains in breeding. Leptin is a $16 \mathrm{kDa}$ protein which is highly expressed in adipose tissue. Leptin is one of the most significant candidate gene marker for MAS studies. Therefore, bubaline leptin gene exon 2, part of the intron 1 and intron 2 region were amplified and sequenced to identify nucleotide variations in Anatolian water buffaloes. Sequence analysis were revealed seven polymorphic site (G1072A, T1081C, T1131G, T1143C, T1145G, T1151G and C1221T) and one monomorphic site (C1071T) in Anatolian water buffaloes. To the best of my knowledge, this is the first study that fully describes seven polymorphic sites of bubaline leptin gene in Anatolian water buffaloes.
\end{abstract}
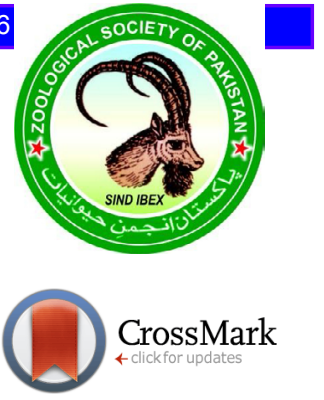

\section{INTRODUCTION}

$\mathrm{M}$ arker assisted selection (MAS) have been widely used to identify the relationships between the genes and economic traits of livestock animals. It's well known that phenotypic values not generally represent the real genotypic values of animals. Therefore, using MAS approaches in selection of animals can increase the accuracy of selection. From this point of view, validation of candidate gene markers for marker assisted selection is very important to increase genetic gains in breeding. Owing to have key biological features, leptin is one of the most significant candidate gene marker for MAS studies (Friedman and Halaas, 1998; Aytekin and Boztepe, 2013; Hristov et al., 2012, 2013; Kök et al., 2017).

Leptin is a $16 \mathrm{kDa}$ protein which is highly expressed in adipose tissue (Frühbeck, 2001). However, Leptin is also expressed in pituitary gland, brain and mammary gland (Morash et al., 1999; Sayed-Ahmed et al., 2003). Leptin plays pivotal role in regulating feed intake and down regulating the adipose tissue storage. Moreover, leptin has also related to appetite, energy balance (Giblin et al., 2010), fertility and immune system (Orrù et al., 2012).

The obesity gene (leptin) first clonned and discovered in 1994 (Zhang et al., 1994). Leptin gene has three exons and two introns and located on chromosome 4 in cattle. (Javanmard et al., 2008). Buffalo leptin gene had three

\footnotetext{
Corresponding author: skaplan@nku.edu.tr 0030-9923/2018/0005-1841 \$9.00/0

Copyright 2018 Zoological Society of Pakistan
}

exons and two introns (GenBank: AH013754.2) and mapped on chromosome 8 (BBU8q32) and consist of 5872 bp (Vallinoto et al., 2004).

Leptin gene shows $67 \%$ sequence similarity between cow, rat, human, rhesus monkey, orangutan, pig, mouse, dog and chimpanzee species (Zhang et al., 1997).

The buffaloes are mostly found in the South and South East Asia of the world. They are usually grown under extreme conditions. They can benefit from low quality roughage in swamp and reed areas (Kelgokmen and Unal, 2015).Turkey's buffalo population (Anatolian water buffaloes) are belongs to the Mediterranean type buffaloes. Anatolian water buffaloes have distributed in Thrace, Black Sea and North of Middle Anatolia region. They can be found Afyon, Kars, Sivas, Muş, Hatayand Diyarbakir province of Turkey (Borghese and Mazzi, 2005). Anatolian water buffalo is generally reared for draught power, milk and meat yield in Turkey (Soysal et al., 2007).

Cattle and buffalo species have important contributions to world agricultural economy with their products. However, cattle is one of the most studied livestock animals in genetic researches. Previous studies have identified many significant associations between genetic markers and economically important traits in dairy and beef cattle (Buchanan et al., 2003; Schenkel et al., 2006). Until today, there were many studies reported strong sequence homology with buffalo and cattle (Kumar et al., 2004; Mahfouz, 2007; de Camargo et al., 2015). Moreover, previous study was also revealed that bubaline leptin gene has strong sequence similarity (97\%) with bovine leptin 
gene (Datta et al., 2012). Therefore, this study was aimed to identify leptin gene nucleotide variations in Anatolian water buffaloes.

\section{MATERIALS AND METHODS}

\section{Sample collection and DNA purification}

A total of 54 Anatolian water buffalo muscle tissue samples were collected after slaughtering and stored at $-20^{\circ} \mathrm{C}$ in a deep freezer as far as molecular genetic studies are performed. The genomic DNA was isolated within the muscle tissue using the GeneMatrix tissue DNA purification kit (Eurx, E3551) as the manufacturer's instructions. The control of isolated DNA was checked in agarose gel electrophoresis.

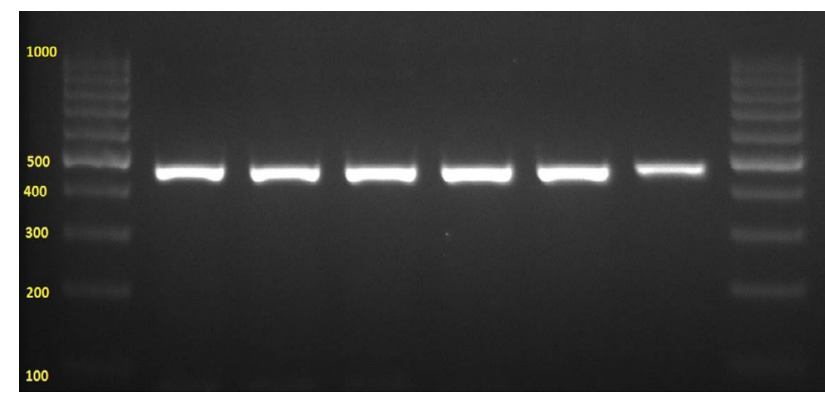

Fig. 1. The PCR product of bubaline leptin gene (461 bp) on agarose gel electrophoresis.

\section{DNA amplification and sequencing \\ The primer pair (Lep forward, GGCTTACTGCTGTGTGGTCT and rreverse,} AATGGCCACGGTTCTACCTC) amplifying the $461 \mathrm{bp}$ DNA fragment (containing the exon 2 and part of the intron 1 and intron 2) was designed using the Primer 3 (NCBI) program (accession AY495587). (C1071T), (G1072A), (T1081C), (T1131G), (T1143C), (T1145G), (T1151G) and $(\mathrm{C} 1221 \mathrm{~T}) \mathrm{SNPs}$ were determined in lactoferrin gene intron 1 and exon 2, respectively. PCR amplifications were performed with the PCR master mix (Thermo, K0171) in accordance with the manufacturer's instructions. The PCRs were carried out in volumes of $25 \mu 1$ using; 12,5 $\mu 1$ Pcr Master Mix, 50 ng ( $5 \mu \mathrm{l})$ genomic DNA, $1 \mu \mathrm{l}(5 \mathrm{pmol})$ each primer, and the rest was ddH2O. The amplification was performed at $95^{\circ} \mathrm{C}$ for $3 \mathrm{~min}$, followed by 35 cycles at $95^{\circ} \mathrm{C}$ for $30 \mathrm{sec}$, annealing at 66 for $30 \mathrm{sec}, 72^{\circ} \mathrm{C}$ for $45 \mathrm{sec}$ and a final extension of $72^{\circ} \mathrm{C}$ for $10 \mathrm{~min}$ on T100 Thermal Cycler (Biorad). The PCR products were subjected to electrophoresis on $2 \%$ agarose/ethidium bromide gel (Aga003R, Bioshop, Canada) in $1 \times$ TAE buffer (TAE-001, New Bioscience). Gels were visualized under UV light and documented in WGD30S Molecular
Imager apparatus (Wisd) (Fig. 1). After the purification and quality analysis; PCR products were sequenced by automated fluorescent sequencing using Quick Start Kit (Beckman Coulter, RN608120) and GenomeLab GeXP DNA analyzer (Beckman Coulter).

\section{Statistical analysis}

In this study, the Chi-square test whether genotype frequencies of all polymorphism were in Hardy Weinberg equilibrium estimated by PopGene Version 1.32 (Yeh et al., 1999).

\section{RESULTS AND DISCUSSION}

In this study, the genetic analysis were performed to identify the polymorphic sites of (C1071T), (G1072A), (T1081C), (T1131G), (T1143C), (T1145G), (T1151G) and (C1221T) (GenBank) of (containing the exon 2, part of the intron 1 and intron 2) bubaline leptin gene in Anatolian water buffaloes. Therefore, the $461 \mathrm{bp}$ DNA fragment (containing the exon 2, part of the intron 1 and intron 2) of bubaline leptin gene in Anatolian water buffaloes were sequenced. And sequence data of this study were analysed by BioEdit Sequence Alignment Editor (Hall, 1999). As a result, the sequence analysis were revealed seven polymorphic site (G1072A, T1081C, T1131G, T1143C, $\mathrm{T} 1145 \mathrm{G}, \mathrm{T} 1151 \mathrm{G}$ and $(\mathrm{C} 1221 \mathrm{~T})$ and one monomorphic site $(\mathrm{C} 1071 \mathrm{~T})$ in Anatolian water buffaloes. Statistical analysis showed that T1143C polymorphic locus was in agreement with Hardy Weinberg equilibrium $(\mathrm{P}<0.05)$. However, G1072A, T1081C, T1131G, T1145G, T1151G and $\mathrm{C} 1221 \mathrm{~T}$ polymorphic locus were not in agreement with Hardy Weinberg equilibrium $(\mathrm{P}<0.05)$. Basic statistics of bubaline leptin gene in Anatolian water buffaloes are given in Table I. The PCR product of bubaline leptin gene (461 $\mathrm{bp)}$ on agarose gel electrophoresis and sequence analysis of (T1131G) are given in Figures 1 and 2, respectively.

In the current study, apart from the Murrah (Datta et al., 2012), Italian and Egyptian Buffaloes (Orrù et al., 2007) the polymorphic site of (C1071T) was found monomorphic in Anatolian water buffaloes. Orrù et al. (2007) have investigated the SNPs of bubaline leptin gene exon 2, exon 3 and part of the intron 1 in Italian and Egyptian Buffaloes. They have identified twelve single nucleotide polymorphisms (G3333A, C1221T, G3195A, C1221T, G3434A, T1015C, C1071T, G1072A, T1081C, T1131G, T1143C, T1145G) in Italian and Egyptian Buffaloes. G3318A polymorphism was found monomorphic in Italian Buffaloes while G3441A polymorphism was reported monomorphic for Italian and Egyptian Buffaloes. Datta et al. (2012) have reported five synonymous SNPs (G983A, C1083T, T1147G, A1152G, 
T1371C) in leptin exon 2 and intron 1 for cattle and Murrah buffaloes. In another study, five SNPs of leptin intron 1 region $(98,111,172,209.266)$ have been identified in Mehsana buffalo (Tanpure et al., 2012). Scatà et al. (2012) have performed sequence analysis of bubaline leptin gene exon 1 and 5' flanking region. They found eight SNPs (A83G, A90G, A121G, G256T, A283G, G959T, A1010C, G1254A) in Mediterranean Italian water buffaloes. Jhala et al. (2009) studied bubaline leptin gene exon 3 region in Mehsana buffalo. Three SNPs the positions at 42, 44, 250 have been found in this study. Vallinoto et al. (2004) studied to identify leptin polymorphism in swamp and river buffalo. They determined two SNPs (276 and 384) bubaline leptin gene exon 3 and one SNP the nucleotide position $137(\mathrm{G} / \mathrm{A})$ in the promoter region. Although, there have been limited scientific reports about the bubaline leptin gene. In contrast, many scientific reports about the associations of leptin gene with economically important traits such as milk yield (Banos et al., 2008), meat quality traits (Schenkel et al., 2005), carcass traits (Buchanan et al., 2002), fertility (Liefers et al., 2002), feed intake (Lagonigro et al., 2003), protein yield and energy balance (Liefers et al., 2005) and body weight (Lusk, 2007) have been reported in dairy and beef cattle.

\section{A}

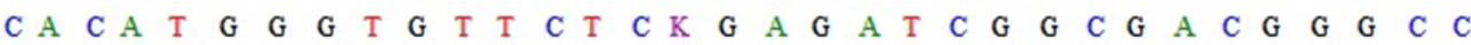
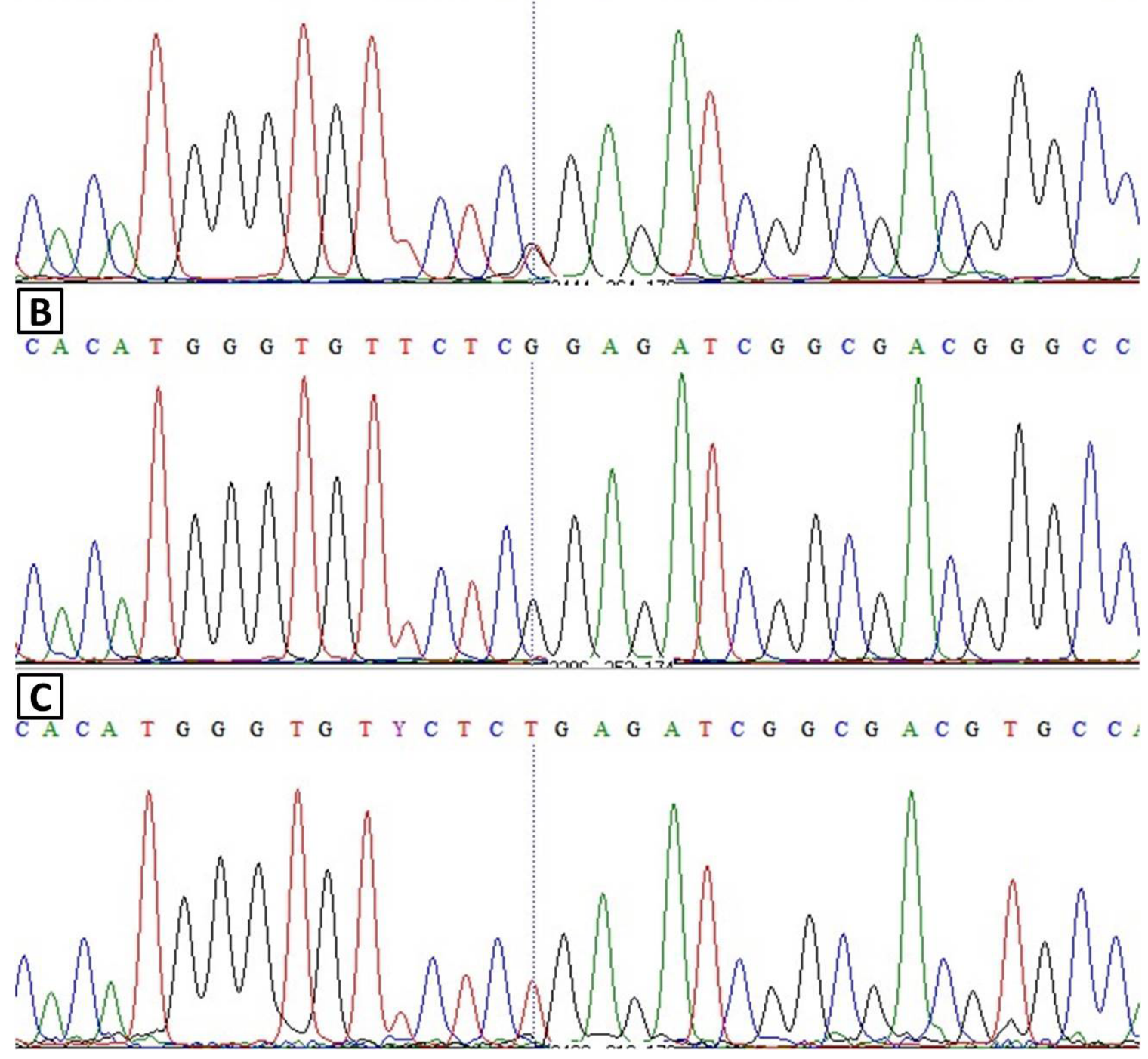

Fig. 2. Sequence analysis of leptin (T1131G) loci. 
Table I.- Basic statistics of bubaline leptin gene in Anatolian water buffaloes.

\begin{tabular}{|c|c|c|c|c|c|}
\hline \multirow[t]{2}{*}{ Loci } & \multicolumn{2}{|c|}{ Allele frequencies } & \multicolumn{2}{|c|}{ Heterozygosity } & \multirow[t]{2}{*}{ Chi-square } \\
\hline & & & Observed & Expected & \\
\hline G1072A & 0.777 (G) & $0.222(\mathrm{~A})$ & 0.8889 & 0.6511 & $25.998775^{\mathrm{s}}$ \\
\hline $\mathrm{T} 1081 \mathrm{C}$ & $0.722(\mathrm{~T})$ & $0.277(\mathrm{C})$ & 0.9259 & 0.5950 & $37.080627^{\mathrm{s}}$ \\
\hline $\mathrm{T} 1131 \mathrm{G}$ & $0.509(\mathrm{~T})$ & $0.490(\mathrm{G})$ & 0.9444 & 0.4955 & $43.569257^{\mathrm{s}}$ \\
\hline $\mathrm{T} 1143 \mathrm{C}$ & $0.981(\mathrm{~T})$ & $0.018(\mathrm{C})$ & 0.9630 & 0.9633 & $0.009524^{\mathrm{NS}}$ \\
\hline $\mathrm{T} 1145 \mathrm{G}$ & $0.203(\mathrm{~T})$ & $0.796(\mathrm{G})$ & 0.9259 & 0.6726 & $33.635561^{\mathrm{s}}$ \\
\hline $\mathrm{T} 1151 \mathrm{G}$ & $0.111(\mathrm{~T})$ & $0.888(G)$ & 1.0000 & 0.8006 & $58.426794^{\mathrm{s}}$ \\
\hline $\mathrm{C} 1221 \mathrm{~T}$ & $0.907(\mathrm{C})$ & $0.092(\mathrm{~T})$ & 0.9259 & 0.8304 & $18.876162^{\mathrm{s}}$ \\
\hline $\mathrm{C} 1071 \mathrm{~T}$ & \multicolumn{5}{|c|}{ Locus monomorphic in Anatolian water buffaloes } \\
\hline
\end{tabular}

${ }^{1} \chi^{2}{ }_{0.05: 1:} 3,84$ test of Hardy-Weingberg equlibrium; S, deviation from Hardy-Weinberg equlibrium is significant; NS, deviation from Hardy-Weinberg equlibrium is not significant.

\section{CONCLUSION}

With advances in molecular genetics in recent years, have providing valuable contributions to improve the efficiency of livestock animals. It is well known that buffalo is high efficient animal that can convert poor quality roughage to milk and meat products. Furthermore, buffalo breeds have high resistance to diseases compared to other livestock animals. To beter understanding the genetic basis of economically important traits and resistance to diseases, it is required to increase genetic researches in buffalo breeds. Leptin is well studied significant genetic marker due to having key biological features in all the species. Therefore, the primary aim of this study was screen nucleotide variations of leptin gene in Anatolian water buffaloes. In summary, this study provided a new report about the findings of seven polymorphic site of leptin gene in Anatolian water buffaloes. And these findings have providing valuable informations for further association studies about the economically important traits of livestock animals.

\section{ACKNOWLEDGEMENTS}

I gratefully acknowledge to Cekmece meat and meat products company for providing tissue samples.

\section{Statement of conflict of interest}

The author declare that there is no conflict of interests regarding the publication of this article.

\section{REFERENCES}

Aytekin, I. and Boztepe, S., 2013. Associations of PIT1gene polymorphism with milk yield and composition traits in brown Swiss cattle. J. Anim. Pl. Sci., 23: 1281-1289.
Banos, G., Woolliams, J., Woodward, B., Forbes, A. and Coffey, M., 2008. Impact of single nucleotide polymorphisms in leptin, leptin receptor, growth hormone receptor, and diacylglycerol acyltransferase (DGAT1) gene loci on milk production, feed, and body energy traits of UK dairy cows. J. Dairy Sci., 91: 3190-3200. https:// doi.org/10.3168/jds.2007-0930

Borghese, A. and Mazzi, M., 2005. Buffalo population and strategies in the world. Buffalo Prod. Res., 67: 1-39.

Buchanan, F.C., Fitzsimmons, C.J., Van Kessel, A.G., Thue, T.D., Winkelman-Sim, D.C. and Schmutz, S.M., 2002. Association of a missense mutation in the bovine leptin gene with carcass fat content and leptin mRNA levels. Genet. Select. Evolut., 34: 105. https://doi.org/10.1186/1297-9686-34-1-105

Buchanan, F., Van Kessel, A., Waldner, C., Christensen, D., Laarveld, B. and Schmutz, S., 2003. Hot topic: an association between a leptin single nucleotide polymorphism and milk and protein yield. J. Dairy Sci., 86: 3164-3166. https://doi.org/10.3168/jds. S0022-0302(03)73918-6

Datta, S., Adikari, A., Chauhan, A., Verma, A., Gupta, I., Chauhan, I., Azad, M.S. and Yathish, H.M., 2012. Nucleotide sequence variation in leptin gene of Murrah buffalo (Bubalus bubalis). Exp. Anim. Med. Res., 2: 130-136.

de Camargo, G., Cardoso, D., Baldi, F., Regitano, L. and Tonhati, H., 2015. Partial sequencing of the TOX and NCOA2 genes in buffaloes. Arch. Zootec., 64: 75-78.

Friedman, J.M. and Halaas, J.L., 1998. Leptin and the regulation of body weight in mammals. Nature, 395: 763-770. https://doi.org/10.1038/27376

Frühbeck, G., 2001. A heliocentric view of leptin. Proc. Nutr. Soc., 60: 301-318. https://doi.org/10.1079/ 


\section{PNS200196}

Giblin, L., Butler, S.T., Kearney, B.M., Waters, S.M., Callanan, M.J. and Berry, D.P., 2010. Association of bovine leptin polymorphisms with energy output and energy storage traits in progeny tested Holstein-Friesian dairy cattle sires. BMC Genet., 11: 73. https://doi.org/10.1186/1471-2156-11-73

Hall, T.A., 1999. BioEdit: A user-friendly biological sequence alignment editor and analysis program for Windows 95/98/NT. Nucleic acids symposium series. Information Retrieval Ltd., London, pp. 9598.

Hristov, P., Teofanova, D., Mehandzhiyski, I., Zagorchev, L. and Radoslavov, G., 2012. Application of milk proteins genetic polymorphism for selection and breeding of dairy cows in Bulgaria. In: Milk production: Advanced genetic traits, cellular mechanism, animal management and health (ed. N. Chaiyabutr). InTech Open, pp. 31-52. https:// doi.org/10.5772/50758

Hristov, P.I., Teofanova, D.R., Mehandzhiyski, I.D., Zagorchev, L.I. and Radoslavov, G.A., 2013. Significance of milk protein genes polymorphism for Bulgarian Rhodopean cattle: Comparative studies. Biotechnol. biotechnol. Equip., 27: 36593664. https://doi.org/10.5504/BBEQ.2012.0132

Javanmard, A., Mohammadabadi, M., Zarrigabayi, G., Gharahedaghi, A., Nassiry, M., Javadmansh, A. and Asadzadeh, N., 2008. Polymorphism within the intron region of the bovine leptin gene in Iranian Sarabi cattle (Iranian Bos taurus). Russian J. Genet., 44: 495-497. https://doi.org/10.1134/ S1022795408040169

Jhala, N., Rank, D., Vataliya, P., Joshi, C., Bhong, C., Mehta, H. and Patil, A., 2009. Cloning and sequencing of the leptin gene in Gir cattle and Mehsana buffalo. Buffalo Bull., 28: 29-33.

Kelgökmen, İ. and Ünal, N., 2015. Anadolu Mandalarında bazı morfometrik özellikler. Lalahan Hay. Araşt. Enst. Derg., 55: 50-55.

Kök, S., Atalay, S., Eken, H.S. and Savaşçi, M., 2017. The genetic characterization of Turkish grey cattle with regard to UoG Cast, CAPN1 316 and CAPN1 4751 markers. Pakistan J. Zool., 49: 297-304. https://doi. org/10.17582/journal.pjz/2017.49.1.281.287

Kumar, P., Choudhary, V., Padma, B., Shukla, A., Misra, A., Bhattacharya, T., Bhushan, B. and Sharma, A., 2004. Buffalo insulin-like growth factor binding protein-3 (IGFBP-3) gene polymorphism and its comparison with cattle. Buffalo J., 20: 183.

Lagonigro, R., Wiener, P., Pilla, F., Woolliams, J. and Williams, J., 2003. A new mutation in the coding region of the bovine leptin gene associated with feed intake. Anim. Genet., 34: 371-374. https://doi. org/10.1046/j.1365-2052.2003.01028.X

Liefers, S., Te Pas, M., Veerkamp, R. and van der Lende, T., 2002. Associations between leptin gene polymorphisms and production, live weight, energy balance, feed intake, and fertility in Holstein heifers. J. Dairy Sci., 85: 1633-1638. https://doi. org/10.3168/jds.S0022-0302(02)74235-5

Liefers, S., Veerkamp, R., Te Pas, M., Delavaud, C., Chilliard, Y., Platje, M. and Lende, T., 2005. Leptin promoter mutations affect leptin levels and performance traits in dairy cows. Anim. Genet., 36: $111-118$. https://doi.org/10.1111/j.13652052.2005.01246.x

Lusk, J., 2007. Association of single nucleotide polymorphisms in the leptin gene with body weight and backfat growth curve parameters for beef cattle. J. Anim. Sci., 85: 1865-1872. https://doi. org/10.2527/jas.2006-665

Mahfouz, E.R., 2007. Sequence and comparative analysis of myeloperoxidase (MPO) in river buffalo (Bubalus bubalis). Australian J. Basic appl. Sci., 1: 533-541.

Morash, B., Li, A., Murphy, P.R., Wilkinson, M. and Ur, E., 1999. Leptin gene expression in the brain and pituitary gland. Endocrinology, 140: 5995-5998. https://doi.org/10.1210/endo.140.12.7288

Orrù, L., Terzano, G., Napolitano, F., Savarese, M., De Matteis, G., Scatä, M., Catillo, G. and Moioli, B., 2007. DNA polymorphisms in river buffalo leptin gene. Italian J. Anim. Sci., 6: 342-344. https://doi. org/10.4081/ijas.2007.s2.342

Orrù, L., Abeni, F., Catillo, G., Grandoni, F., Crisà, A., De Matteis, G., Carmela Scatà, M., Napolitano, F. and Moioli, B., 2012. Leptin gene haplotypes are associated with change in immunological and hematological variables in dairy cow during the peripartum period. J. Anim. Sci., 90: 16-26. https:// doi.org/10.2527/jas.2010-3706

Sayed-Ahmed, A., Elmorsy, S.E., Rudas, P. and Bartha, T., 2003. Partial cloning and localization of leptin and leptin receptor in the mammary gland of the Egyptian water buffalo. Domest. Anim. Endocrinol., 25: 303-314. https://doi.org/10.1016/ S0739-7240(03)00057-2

Scatà, M., Grandoni, F., Antonelli, S., De Matteis, G. and Napolitano, F., 2012. Single nucleotide polymorphisms detected and in silico analysis of the 5 'flanking sequence and exon 1 in the Bubalus bubalis leptin gene. J. Buffalo Sci., 1: 73-77.

Schenkel, F., Miller, S., Ye, X., Moore, S., Nkrumah, 
J., Li, C., Yu, J., Mandell, I., Wilton, J. and Williams, J., 2005. Association of single nucleotide polymorphisms in the leptin gene with carcass and meat quality traits of beef cattle 1. J. Anim. Sci., 83: 2009-2020. https://doi.org/10.2527/2005.8392009x

Schenkel, F., Miller, S., Jiang, Z., Mandell, I., Ye, X., Li, H. and Wilton, J., 2006. Association of a single nucleotide polymorphism in the calpastatin gene with carcass and meat quality traits of beef cattle 1. J. Anim. Sci., 84: 291-299. https://doi. org/10.2527/2006.842291x

Soysal, M., Tuna, Y., Gurcan, E., Ozkan, E., Kok, S., Castellano, N., Cobanoglu, O. and Barone, C., 2007. Anatolian water buffaloes husbandry in Turkey: Preliminary results on somatic characterization. Italian J. Anim. Sci., 6: 1302-1307. https://doi. org/10.4081/ijas.2007.s2.1302

Tanpure, T., Dubey, P.K., Singh, K.P., Kathiravan, P., Mishra, B.P., Niranjan, S.K. and Kataria, R.S., 2012. PCR-SSCP analysis of leptin gene and its association with milk production traits in river buffalo (Bubalus bubalis). Trop. Anim. Hlth. Prod., 44: 1587-1592. https://doi.org/10.1007/s11250012-0111-7

Vallinoto, M., Schneider, M., Silva, A., Iannuzzi, L. and Brenig, B., 2004. Molecular cloning and analysis of the swamp and river buffalo leptin gene. Anim. Genet., 35: 462-463. https://doi.org/10.1111/j.13652052.2004.01186.x

Yeh, F., Yang, R. and Boyle, T., 1999. Popgene version 1.32: Microsoft Windows-based freeware for population genetic analysis. University of Alberta, Edmonton.

Zhang, Y., Proenca, R., Maffei, M., Barone, M., Leopold, L. and Friedman, J.M., 1994. Positional cloning of the mouse obese gene and its human homologue. Nature, 372: 425. https://doi.org/10.1038/372425a0

Zhang, F., Basinski, M.B., Beals, J.M., Briggs, S.L., Churgay, L.M., Clawson, D.K., DiMarchi, R.D., Furman, T.C., Hale, J.E. and Hsiung, H.M., 1997. Crystal structure of the obese protein Ieptin-E100. Nature, 387: 206. https://doi.org/10.1038/387206a0 